\title{
Eosinophilic esophagitis in Egyptian adult patients presenting with upper gastrointestinal symptoms
}

\author{
Shereen Shoukry Hunter ${ }^{1}$, Dina Omar Helmy ${ }^{2}$, Naglaa Aly Zayed ${ }^{1}$, Tamer Mohamed El-Tayeb ${ }^{3}$, \\ Magdy Amin El-Serafy ${ }^{1}$ \\ ${ }^{1}$ Endemic Medicine Department and Gastrointestinal Endoscopy and Liver Unit, Faculty of Medicine, Cairo University, Cairo, Egypt \\ ${ }^{2}$ Pathology Department, Faculty of Medicine, Cairo University, Cairo, Egypt \\ ${ }^{3}$ Endoscopy Unit, New Kasr El-Ainy Teaching Hospital, Cairo, Egypt \\ Email: shereenhunter@hotmail.com
}

Received 4 January 2014; revised 3 February 2014; accepted 9 February 2014

Copyright (C) 2014 Shereen Shoukry Hunter et al. This is an open access article distributed under the Creative Commons Attribution License, which permits unrestricted use, distribution, and reproduction in any medium, provided the original work is properly cited. In accordance of the Creative Commons Attribution License all Copyrights (c) 2014 are reserved for SCIRP and the owner of the intellectual property Shereen Shoukry Hunter et al. All Copyright (C) 2014 are guarded by law and by SCIRP as a guardian.

\section{ABSTRACT}

Background and Study Aim: Eosinophilic esophagitis (EoE) is a clinicopathological disease characterized by esophageal dysfunction and marked esophageal eosinophilic infiltration. It shows a marked increase in incidence and prevalence and has been associated with gastroesophageal reflux disease (GERD). The aim of this work was to detect the prevalence of EoE in Egyptian adult patients presenting with upper gastrointestinal symptoms and to clarify its clinical pattern and the possibility of its overlap with GERD. Patients and Methods: The study included 91 adult patients presenting with various upper gastrointestinal symptoms. Upper gastrointestinal endoscopy was done and esophageal biopsies were taken. The presence of $>15$ eosinophils per high power field together with a history of intake of proton pump inhibitors for at least 3 weeks without improvement was used as prerequisite diagnostic criteria for EoE. Results: Classification of the patients was based on both endoscopic and histopathological findings. Accordingly, out of the 91 patients, 70 had GERD (76.9\%); 58 of them had erosive reflux disease (ERD) and 12 had endoscopically normal esophagus but with histopathological changes compatible with reflux esophagitis and were classified as non erosive reflux disease (NERD). Eighteen patients had normal endoscopic and histopathological esophagus (19.8\%), and 3 patients had EoE (3.3\%), with an overlap between ERD and EoE in one patient. The mean age of EoE patients was $41.6 \pm 11.7$ years. Two of them were males and one was a female. All of the 3 patients complained of dysphagia and none complained of heartburn. The endoscopists did not report any endoscopic findings characteristic of EoE. Con- clusion: The prevalence of EoE is low in adult Egyptian patients presenting with upper gastrointestinal symptoms. Dysphagia is the main presenting symptom of EoE while heartburn is not characteristic of the disease. Normal esophagus endoscopically does not exclude EoE.

\section{KEYWORDS}

Eosinophilic Esophagitis (EoE); Adults;

Gastroesophageal Reflux Disease (GERD); Egypt

\section{INTRODUCTION}

Eosinophilic esophagitis (EoE) is a chronic immune/antigen-mediated esophageal disease characterized clinically by symptoms related to esophageal dysfunction and histologically by eosinophil-predominant inflammation [1]. It was thought to be a rare inflammatory condition in adults [2] with an estimated prevalence 0.2 - 3 in 10,000 [3]. However, the epidemiology of EoE has been rapidly evolving over the past two decades, with a marked increase in incidence and prevalence [4] and it has become increasingly recognized as an important cause of dysphagia and food impaction in adults [5]. This is likely attributable to a combination of an increasing incidence and a growing awareness of the condition amongst gastroenterologists and pathologists [6]. EoE has recently been associated with gastroesophageal reflux disease (GERD) [7-9]. It mimics GERD and may result in narrowing and stricture of the esophagus [10-12]. This disease is differentiated from reflux esophagitis on the basis of the magnitude of mucosal eosinophilia and a lack of response to acid suppression [13]. 


\section{AIM OF THE WORK}

The aim of this study was to detect the prevalence of EoE in Egyptian adult patients presenting with upper gastrointestinal symptoms and to clarify its clinical pattern as well as the possibility of its overlap with GERD.

\section{PATIENTS AND METHODS}

The study included 91 adult patients presenting with various upper gastrointestinal symptoms as heartburn, dysphagia/odynophagia, eructation, epigastric pain and vomiting, and who were on acid suppression therapy [either proton pump inhibitors (PPIs) or histamine $\mathrm{H}_{2}$ receptor antagonists $\left.\left(\mathrm{H}_{2} \mathrm{RA}\right)\right]$. Patients on any form of steroids were excluded. Patients were recruited from the Endoscopy Units of Cairo University Hospital and New Kasr El-Ainy Teaching Hospital, Cairo, Egypt in the period from December 2009 to December 2011 and the study was approved by the local ethical committee.

Patients were clinically assessed with special emphasis on history of smoking, any allergic manifestations such as bronchial asthma and allergic rhinitis, and relevant drug history.

Midazolam or propofol were used for sedation then upper gastrointestinal endoscopy was done. The endoscopist noted the following:

- The presence of endoscopic findings of EoE which include esophageal rings, strictures, narrow-caliber esophagus, linear furrows, white plaques or exudates and pallor or decreased vasculature [14,15].

- The presence of erosive reflux disease (ERD) which was classified according to the Los Angeles Classification System [16].

- Any other finding in the esophagus, stomach or duodenum was reported.

Biopsies were taken from mid-esophagus and, in cases of ERD, lower esophageal biopsies were done as well. All esophageal mucosal biopsy specimens were fixed in formalin, routinely processed, embedded in paraffin and cut serially in 5-micron sections. Biopsies were examined by the same histopathologist after staining with haematoxylin and eosin. GERD was diagnosed after fulfillment of its histopathological criteria such as epithelial edema and basal cell hyperplasia, elongation of the papillae, thinning of the squamous cell layer plus lymphocytic or neutrophilic inflammation. Goblet cell metaplasia or Barrett's esophagus was identified and recorded.

On the high power field (HPF) the pathologist counted the eosinophils in all biopsies. The presence of $>15$ eosinophils/HPF together with a history of intake of PPIs for at least 3 weeks without improvement were used as prerequisite diagnostic criteria for EoE.

\section{STATISTICAL ANALYSIS}

Data were statistically described in terms of frequencies (number of cases) and percentages. Comparison between the study groups was done using Chi-square $\left(\chi^{2}\right)$ test. Exact test was used instead when the expected frequency was less than 5. $P$ value less than 0.05 was considered statistically significant. All statistical calculations were done using computer programs SPSS (Statistical Package for the Social Science; SPSS Inc., Chicago, IL, USA) version 15 for Microsoft Windows.

\section{RESULTS}

The mean age of all patients was $43.06 \pm 9.9$ years (minimum $=21$, maximum $=65$ years). They were 56 males (61.5\%) and 35 females (38.4\%). Thirty patients (32.9\%) gave history of smoking, 65 (71\%) gave history of use of PPIs and 26 (28.5\%) gave history of use of $\mathrm{H}_{2} \mathrm{RA}$.

The presenting symptoms of the patients were epigastric pain in 56 (61\%), vomiting in 49 (53.8\%), dysphagia/ odynophagia in 33 (36.2\%), heartburn in 27 (29.7\%) and food impaction in 3 (3.8\%) of patients.

Endoscopically, a total of 58 patients had ERD; 38 (41.8\%) had grade A, 19 (20.9\%) had grade B and only 1 patient $(1.1 \%)$ had grade $C$. No cases with grade $D$ were encountered. Eleven of them (12\% of patients) had also hiatus hernia. Thirty eight patients (41.7\%) had erythematous gastritis, 32 (35.1\%) had endoscopically normal esophagus, 19 (20.8\%) had erosive gastritis, 14 (15.3\%) had duodenal ulcer or erosion, and 9 (9.8\%) had gastric ulcer. One patient had only hiatus hernia and only 1 was found to have Barrett's esophagus. The endoscopists did not report any endoscopic findings characteristic of EoE.

Histopathological examination of esophageal biopsies revealed histopathological findings of reflux esophagitis in $69(75.8 \%)$ of patients, normal stratified squamous epithelium in 18 (20\%), EoE in 3 (3.3\%) and Barrett's esophagus in only 1 patient. One of the EoE cases had histopathological findings of reflux esophagitis.

Our classification of the patients was based on both histopathological and endoscopic findings as shown in Table 1. Accordingly, out of the 91 patients, 70 had GERD (76.9\%); 58 of them had ERD (82.9\% of GERD patients; $63.7 \%$ of all patients) and 12 (17.1\% of GERD patients; $13.2 \%$ of all patients) had endoscopically normal esophagus but with histopathological changes compatible with reflux esophagitis and were classified as non-erosive reflux disease (NERD) as they all also complained of heart-burn. Eighteen patients had normal endoscopic and histopathological esophagus (19.8\%), and 3 patients had EoE (3.3\%) (Figures 1 and 2), with an overlap between ERD and EoE in one patient.

The mean age of EoE patients was $41.6 \pm 11.7$ years (minimum $=33$, maximum $=55$ years $)$. Two were males and one was a female. All 3 patients complained of dysphagia. None of them was a smoker and one (33.3\%) had history of bronchial asthma. Two had a normally appear- 
Table 1. Patterns of esophageal mucosal injury and the subsequent group classification.

\begin{tabular}{|c|c|c|c|}
\hline $\begin{array}{l}\text { Pattern of mucosal } \\
\text { injury }\end{array}$ & $\begin{array}{l}\text { Positive endoscopy and } \\
\text { histopathology ( } N=59)\end{array}$ & $\begin{array}{l}\text { Negative endoscopy and } \\
\text { histopathology }(\mathrm{N}=18)\end{array}$ & $\begin{array}{l}\text { Negative endoscopy/positive } \\
\text { histopathology }(\mathrm{N}=14)\end{array}$ \\
\hline Group classification & $\begin{array}{c}\text { ERD }(\mathrm{N}=57) \\
\text { ERD }+ \text { EE }(\mathrm{N}=1) \\
\text { Barrett's esophagus }(\mathrm{N}=1)\end{array}$ & Normal esophagus & $\begin{array}{l}\operatorname{NERD}(\mathrm{N}=12) \\
\operatorname{EoE}(\mathrm{N}=2)\end{array}$ \\
\hline
\end{tabular}

ERD: erosive reflux disease. NERD: non erosive reflux disease. EoE: eosinophilic esophagitis.

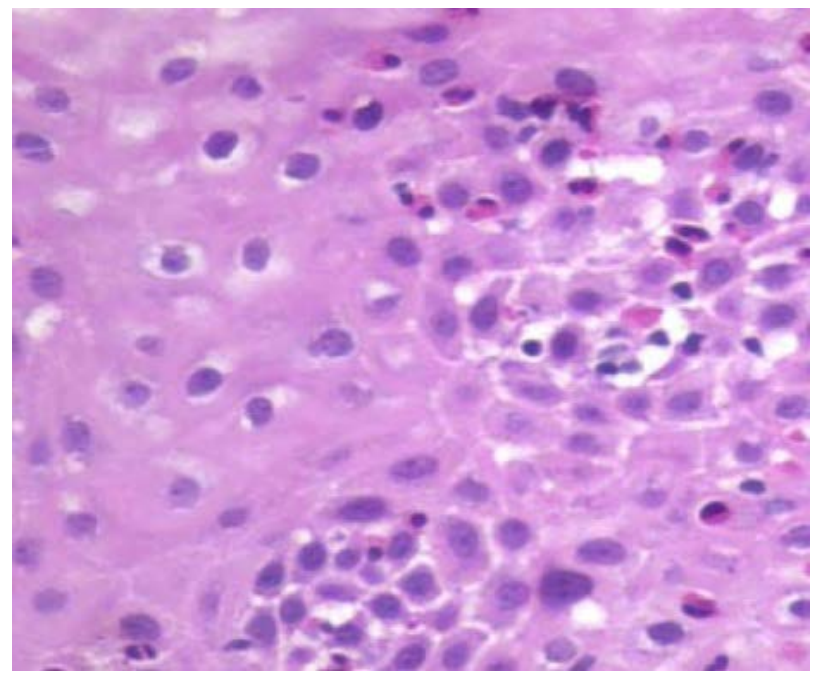

Figure 1. Case histologically diagnosed as eosinophilic esophagitis (EoE): a section in esophageal mucosa shows many intraepithelial eosinophils (23 eosinophils). The superficial position of the eosinophilic infiltrate is also noted (hematoxylin and eosin stained section, original magnification $\times 200$ ).

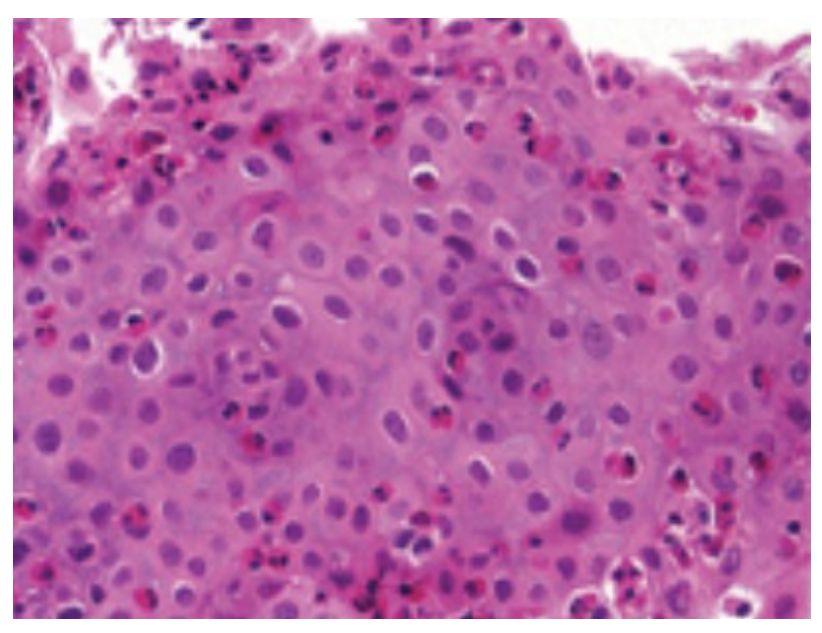

Figure 2. Esophageal mucosa from another case of eosinophilic esophagitis (EoE): intraepithelial eosinophils (58 eosinophils) were detected. Of notice also is the intercellular edema giving the spongy or moth eaten appearance (hematoxylin and eosin stained section, original magnification $\times 200$ ).

ing esophagus endoscopically, 1 had additional ERD and non had any detectable endoscopic findings in stomach or duodenum.

Associations between endoscopic and histopathologi- cal findings with the presenting symptoms are shown in Table 2. Dysphagia occurred more significantly in EoE patients $(p$ value $=0.020)$ and heartburn occurred more significantly in patients with NERD in relation to other presenting symptoms. None of the symptoms showed statistically significant occurrence among different groups.

The patient with Barrett's esophagus manifested clinically by heartburn.

\section{DISCUSSION}

EoE is a clinicopathologic disease characterized clinically by symptoms related to esophageal dysfunction. Pathologically there must be eosinophil-predominant inflammation in one or more biopsy specimens. The disease is isolated to the esophagus, and other causes of esophageal eosinophilia should be excluded, specifically PPIresponsive esophageal eosinophilia. The disease should remit with treatments of dietary exclusion, topical corticosteroids, or both [1]. The epidemiology of EoE may be changing; several case reports and case series suggest that either the incidence is increasing or the disease is now recognised more often [14,17].

The aim of this work was to detect the prevalence of EoE in adult Egyptian patients presenting with various upper gastrointestinal symptoms as well as to clarify its clinical pattern as well as the possibility of its overlap with GERD.

The lack of a clinicopathologic response to PPI treatment in patients adherent to the treatment regimen with compatible symptoms of EoE and isolated esophageal eosinophilia is consistent with the diagnosis of EoE [18]. With few exceptions, 15 eosinophils/HPF (peak value) is considered a minimum threshold for a diagnosis of EoE [1]. In our study, the presence of $>15$ eosinophils/HPF together with a history of intake of PPIs for at least 3 weeks without improvement were used as prerequisite diagnostic criteria for EoE.

We found 3 cases of EoE out of 91 adult patients presenting with various upper gastrointestinal symptoms (3.3\%). The prevalence of EoE varies with the population studied. For example, it has been estimated to be $0.4 \%$ - $1.1 \%$ in the general population $[19,20]$, in an out-patient population undergoing routine upper endoscopy the prevalence increased to $6.5 \%$ [21], and in those undergoing an endoscopy for dysphagia, the prevalence was $10 \%$ - 
Table 2. Association of histopathological and endoscopic findings with presenting symptoms.

\begin{tabular}{cccc}
\hline & \multicolumn{3}{c}{ Findings } \\
\hline Symptoms & $\begin{array}{c}\text { NERD } \\
(\mathbf{N}=\mathbf{1 2})\end{array}$ & $\begin{array}{c}\text { ERD } \\
\mathbf{( N = 5 8 )}\end{array}$ & $\begin{array}{c}\text { EoE } \\
\mathbf{( N ~ = ~ 3 ) ~}\end{array}$ \\
Dysphagia & 6 & 20 & $3^{*}$ \\
\% & $50 \%$ & $34.4 \%$ & $100 \%$ \\
Food impaction & 1 & 1 & 0 \\
\% & $8.3 \%$ & $1.7 \%$ & $0 \%$ \\
Heartburn & $12^{*}$ & 21 & 0 \\
\% & $100 \%$ & $36.2 \%$ & $0 \%$ \\
Epigastric pain & 9 & 36 & 2 \\
\% & $75 \%$ & $62 \%$ & $66.6 \%$ \\
Vomiting & 11 & 32 & 1 \\
\% & $91.6 \%$ & $55.1 \%$ & $33.3 \%$ \\
\hline
\end{tabular}

Chi-square test. $\left(^{*}\right)$ denotes statistically significant occurrence of the relevant symptom within the same studied group. NERD: non erosive reflux disease. ERD: erosive reflux disease. EoE: eosinophilic esophagitis.

$15 \%$ [22-24].

Most EoE studies report a male predominance, including $>75 \%$ of reported adult and child cases [10]. In the current study, the mean age of EoE patients was $41.6 \pm$ 11.7 years, and EoE was detected in males more than females ( 2 males and 1 female). Compared with EoE negative patients, EoE positive patients in the study by Veerappan et al, [21] were more likely to be male and younger than 50 years. Among 41 subjects with histological EoE, the ratio of males to females was $4: 1$ and the average age at diagnosis was 45 years [25].

Several lines of evidence support a role for allergic inflammation in the pathogenesis of EoE. The most obvious evidence for such involvement is the central role of the eosinophil which is often considered synonymous with allergic disease because of its accumulation in sputum in asthma, in nasal secretions in allergic rhinitis and in the skin during flares of acute eczema [26]. Among adults with EoE, studies report personal or family histories of allergies ranging from 50 to $90 \%$, including up to $60 \%$ with asthma and up to $25 \%$ with food allergies [2, 12,27]. Although clearly an atopic condition, the role of specific allergic triggers in EoE remains unclear [28]. In our study, 33.3\% of the EoE patients had history of bronchial asthma. Compared with EoE negative patients, EoE positive patients were more likely to have asthma (32.0\% vs $10.8 \%$ ) [21] and 14 of 29 patients (48\%) with documented EoE had a history of asthma, environmental allergy, or atopy [27].

The symptom profile is similar to that of severe GERD, but unlike GERD, EoE is not resolved with acid reduction therapy, such as antacids, PPIs, and $\mathrm{H}_{2} \mathrm{RA}$. Symptoms of EoE vary with age $[5,29,30]$. Common presenting symptoms in adults include dysphagia, food impaction, heartburn and chest pain [5]. The typical symptoms of GERD patients are heartburn and regurgitation [31]. In the current study, the main presenting symptom of EoE patients was dysphagia which was present in all 3 patients with EoE $(100 \%)$ ( $p$ value $=0.020$ ). None of EoE patients complained of food impaction. In an earlier study, dysphagia was documented in 26 of 31 EoE patients (89\%) [2]. Also, food impaction was found in 32.0\% of EoE positive patients and dysphagia in 64.0\% [21] and the most common endoscopy indications in adults with EoE were dysphagia (70.1\%) and GERD/heartburn (27.1\%) [32]. Heartburn was the presenting symptom in $36.2 \%$ of ERD patients in our study, in $100 \%$ of NERD patients (which was a statistically significant finding in this group), and in none of EoE patients. In the study by Parfitt et al. [25], dysphagia was more common in EoE patients (63\%), while heartburn was more common in none EoE patients (53\%) who were regarded to represent patients with GERD.

Endoscopic findings of EoE include esophageal rings, strictures, narrow-caliber esophagus, linear furrows, white plaques or exudates, and pallor or decreased vasculature $[14,15]$. Two of the 3 positive cases of EoE in our study (66\%) showed normal endoscopic appearance of the esophagus and the third had an overlap with ERD. However, the small number of patients found to have EoE in our study may have precluded us from stating a specific endoscopic finding for this disease. Besides, the endoscopic features of EoE may be subtle and overlooked at endoscopy [2,33]. One adult series of histologically confirmed EoE reported $8.8 \%$ of patients without any apparent endoscopic features [14]. In a meta-analysis, the endoscopic examination was normal in $17 \%$ of cases [34]. However, esophageal mucosal furrows were present in 30 of $31 \mathrm{EoE}$ patients (97\%) [2] and the presence of classic findings of EoE on endoscopy (rings, furrows, plaques, or strictures) was the strongest predictor of this disease process with a sensitivity of $72 \%$, specificity of $89 \%$, and negative predictive value of $98 \%$ [21]. On the other hand, Machenzie et al. [35] found that 13/31 (42\%) of EoE patients did not have the classic endoscopic findings (rings +/- furrows) and would have been missed without esophageal biopsies. Consequently, although a high degree of suspicion for EoE must be maintained for patients that have endoscopic features of this disease, the presence or absence of endoscopic findings is insufficient to make a diagnosis. Esophageal biopsies should be obtained from all patients who present with symptoms of EoE, regardless of the endoscopic appearance of the esophagus [34]. Also, it is advised that esophageal biopsies routinely be taken in the clinical setting of unexplained dysphagia, refractory heartburn, or chest pain regardless of endoscopic findings as endoscopic mucosal biopsy remains the most important diagnostic test for EoE and the diagnosis of EoE is ultimately established histologically 
[5]. Esophageal biopsies demonstrate often marked epithelial basal hyperplasia and extensive infiltration of the epithelium by eosinophils. The changes occur not just in the distal esophagus, as in GERD, but also in the mid and upper esophageal mucosa, a feature that is often useful in the differentiation of EoE from reflux esophagitis. Eosinophils generally number in excess of 20 to 24/HPF [36, 37]. There are limited data to support routine gastric or duodenal biopsies in adults in the absence of symptoms or endoscopic abnormalities suggesting other gastrointestinal disorders, although it is reasonable for these biopsies to be performed [1].

In 1985, Lee [38] reported on 11 patients with obvious esophageal eosinophil infiltration, 10 of whom had reflux esophagitis. Since then, the connection between GERD and EoE has been under debate $[3,27,33,39]$. Historically, the diagnosis of EoE was often overlooked in adults with many patients alternatively diagnosed as having GERD or a Schatzki ring. In some instances, these patients had undergone repeated endoscopies and dilation prior to accurate diagnosis [40,41]. Another historical explanation for the delayed diagnosis of EoE is that eosinophilic infiltrate in the esophageal mucosa was previously equated with GERD [42]. Accepting that that can be the case, the current strategy for making this distinction is to rely on a quantitative threshold of eosinophilic infiltration (currently $\geq 15 / \mathrm{HPF}$ in the area of greatest eosinophilic infiltration); lower counts are presumed related to GERD whilst higher counts are diagnostic of EoE [5].

GERD is extremely common, with an incidence of 10 to $20 \%$ in Western adults presenting with reflux symptoms and heartburn [43] and is the most common disease in patients referred for upper endoscopy [44]. The prevalence of GERD in our patients was $76.9 \%$. In the 3 cases of EoE, one (33.3\%) had also features of ERD. The overlap between GERD and EoE continues to be enigmatic because of the high prevalence of GERD in the adult population. In nine adult EoE studies reporting $\mathrm{pH}$ monitoring data, abnormal results were reported in $18 \%$ of patients [5]. In a systematic review, pathological acid reflux was found in only $10 \%$ of cases of EoE [14]. Among patients with GERD, 8.8\% had EoE [45]. It is now suggested that EoE is more prevalent among GERD patients who do not respond to treatment with PPIs [5, 46]. An initial trial of PPI therapy in patients with clini$\mathrm{cal}$, endoscopic and pathologic findings of EoE is thus warranted. Lack of a response to PPI may reinforce a diagnosis of EoE, but a clinical response to PPI may not rule out quiescent EoE. Esophageal $\mathrm{pH}$ measurements and histopathologic data on patients on PPI treatment are pivotal in cases with overlapping GERD and EoE in order to evaluate the role of each disease [46].

It has been documented that up to $70 \%$ of reflux pa- tients have typical reflux symptoms (i.e., heartburn and/ or regurgitation) in the absence of endoscopically visible esophageal mucosal injuries, making NERD the more common form of GERD $[47,48]$. In the current study, only $17.1 \%$ of GERD patients had NERD diagnosed on the basis of the presence of heartburn and histopathological changes compatible with reflux esophagitis in a normal endoscopic esophagus. The changes were detected in mid-esophageal biopsies. There has been little standardization of biopsy techniques or tissue processing in GERD and NERD patients. Biopsies have been obtained at the squamocolumnar junction, or at $1,2,3$ and $5 \mathrm{~cm}$ above it. Furthermore, there is no consensus on the number of biopsy specimens obtained, or the location around the inner circumference of the esophagus at which biopsies should be taken. This issue is especially important since the severity of exposure to refluxate decreases with increasing distance from squamocolumnar junction and the distribution of mucosal injury may be patchy [49]. However, in the attempt to better understand the mechanisms involved in the perception of gastroesophageal reflux, some observations have pointed out the role of the acid extent into the middle-proximal esophagus [50-55]. Indeed, in NERD patients, independently of the acid exposure time, reflux episodes reaching the proximal esophagus were perceived more than those confined to the distal esophagus [51,55].

\section{CONCLUSION}

In conclusion, the prevalence of EoE is low in adult Egyptian patients presenting with upper gastrointestinal symptoms. Dyshagia is the main presenting symptom of EoE while heartburn is more common in GERD. Normal endoscopic esophagus does not exclude EoE.

\section{REFERENCES}

[1] Liacouras, C.A., Furuta, G.T., Hirano, I., Atkins, D., Attwood, S.E., Bonis, P.A., Burks, A.W., Chehade, M., Collins, M.H., Dellon, E.S., Dohil, R., Falk, G.W., Gonsalves, N., Gupta, S.K., Katzka, D.A., Lucendo, A.J., Markowitz, J.E., Noel, R.J., Odze, R.D., Putnam, P.E., Richter, J.E., Romero, Y., Ruchelli, E., Sampson, H.A., Schoepfer, A., Shaheen, N.J., Sicherer, S.H., Spechler, S., Spergel, J.M., Straumann, A., Wershil, B.K., Rothenberg, M.E. and Aceves, S.S. (2011) Eosinophilic esophagitis: Updated consensus recommendations for children and adults. Journal of Allergy and Clinical Immunology, 128, 3-20. http://dx.doi.org/10.1016/j.jaci.2011.02.040

[2] Croese, J., Fairley, S.K., Masson, J.W., Chong, A.K., Whitaker, D.A., Kanowski, P.A. and Walker, N.I. (2003) Clinical and endoscopic features of eosinophilic esophagitis in adults. Gastrointest Endosc, 58, 516-522. http://dx.doi.org/10.1067/S0016-5107(03)01870-4

[3] Straumann, A. and Beglinger, C. (2006) Eosinophilic esophagitis: The endoscopist's enigma. Gastrointest Endosc, 
63, 13-15. http://dx.doi.org/10.1016/j.gie.2005.09.010

[4] Dellon, E.S, Erichsen, R., Pedersen, L., Shaheen, N.J., Baron, J.A., Sørensen, H.T. and Vyberg, M. (2013) Development and validation of a registry-based definition of eosinophilic esophagitis in Denmark. World Journal of Gastroenterology, 19, 503-510.

http://dx.doi.org/10.3748/wjg.v19.i4.503

[5] Furuta, G.T., Liacouras, C.A., Collins, M.H., Gupta, S.K., Justinich, C., Putnam, P.E., Bonis, P., Hassall, E., Straumann, A., Rothenberg, M.E. and Members of the First International Gastrointestinal Eosinophil Research Symposium (FIGERS) Subcommittees (2007) Eosinophilic esophagitis in children and adults: A systematic review and consensus recommendations for diagnosis and treatment. Gastroenterology, 133, 1342-1363.

http://dx.doi.org/10.1053/j.gastro.2007.08.017

[6] Gonsalves, N. and Kahrilas, P.J. (2009) Eosinophilic oesophagitis in adults. Neurogastroenterology \& Motility, 21, 1017-1026. http://dx.doi.org/10.1111/j.1365-2982.2009.01307.x

[7] Sgouros, S.N. (2006) Refractory heartburn to proton pump inhibitors: Epidemiology, etiology and management. Digestion, 73, 218-227.

[8] Richter, J.E. (2007) How to manage refractory GERD. Nature Clinical Practice Gastroenterology \& Hepatology, 4, 658-664. http://dx.doi.org/10.1038/ncpgasthep0979

[9] Fass, R. and Gasiorowska, A. (2008) Refractory GERD: What is it? Current Gastroenterology Reports, 10, 252257. http://dx.doi.org/10.1007/s11894-008-0052-5

[10] Fox, V.L., Nurko, S. and Furuta, G.T. (2002) Eosinophilic esophagitis: It's not just kid's stuff. Gastrointest Endosc, 56, 260-270. http://dx.doi.org/10.1016/S0016-5107(02)70188-0

[11] Vasilopoulos, S., Murphy, P., Auerbach, A., Massey, B.T., Shaker, R., Stewart, E., Komorowski, R.A. and Hogan, W.J. (2002) The small-caliber esophagus: An unappreciated cause of dysphagia for solids in patients with eosinophilic esophagitis. Gastrointest Endosc, 55, 99-106. http://dx.doi.org/10.1067/mge.2002.118645

[12] Straumann, A., Spichtin, H.P., Grize, L., Bucher, K.A., Beglinger, C. and Simon, H.U. (2003) Natural history of primary eosinophilic esophagitis: A follow-up of 30 adult patients for up to 11.5 years. Gastroenterology, 125, 1660-1669. http://dx.doi.org/10.1053/j.gastro.2003.09.024

[13] Ruchelli, E., Wenner, W., Voytek, T., Brown, K. and Liacouras, C. (1999) Severity of esophageal eosinophilia predicts response to conventional gastroesophageal reflux therapy. Pediatric and Developmental Pathology, 2, 1518. http://dx.doi.org/10.1007/s100249900084

[14] Sgouros, S.N., Bergele, C. and Mantides, A. (2006) Eosinophilic esophagitis in adults: A systematic review. European Journal of Gastroenterology \& Hepatology, 18, 211-217. http://dx.doi.org/10.1097/00042737-200602000-00015

[15] Dellon, E.S., Gibbs, W.B., Fritchie, K.J., Rubinas, T.C., Wilson, L.A., Woosley, J.T. and Shaheen, N.J. (2009) Clinical, endoscopic, and histologic findings distinguish eosinophilic esophagitis from gastroesophageal reflux dis- ease. Clinical Gastroenterology and Hepatology, 7, 13051313. http://dx.doi.org/10.1016/j.cgh.2009.08.030

[16] Armstrong, D., Bennett, J.R., Blum, A.L., Dent, J., De Dombal, F.T., Galmiche, J.P., Lundell, L., Margulies, M., Richter, J.E., Spechler, S.J., Tytgat, G.N. and Wallin, L. (1996) The endoscopic assesment of esophagitis: A progress report on observer agreement. Gastroenterology, 111, 85-92.

http://dx.doi.org/10.1053/gast.1996.v111.pm8698230

[17] Straumann, A. and Simon, H.U. (2005) Eosinophilic esophagitis: Escalating epidemiology? Journal of Allergy and Clinical Immunology, 115, 418-419.

http://dx.doi.org/10.1016/j.jaci.2004.11.006

[18] Spergel, J.M., Brown-Whitehorn, T.F., Beausoleil, J.L., Franciosi, J., Shuker, M., Verma, R. and Liacouras, C.A. (2009) 14 years of eosinophilic esophagitis: Clinical features and prognosis. Journal of Pediatric Gastroenterology and Nutrition, 48, 30-36. http://dx.doi.org/10.1097/MPG.0b013e3181788282

[19] Almansa, C., Devault, K.R. and Achem, S.R. (2011) A comprehensive review of eosinophilic esophagitis in adults. Journal of Clinical Gastroenterology, 45, 658664. http://dx.doi.org/10.1097/MCG.0b013e318211f95b

[20] Ronkainen, J., Talley, N.J., Aro, P., Storskrubb, T., Johansson, S.E., Lind, T., Bolling-Sternevald, E., Vieth, M., Stolte, M., Walker, M.M. and Agréus, L. (2007) Prevalence of oesophageal eosinophils and eosinophilic oesophagitis in adults: The population-based Kalixanda study. Gut, 56, 615-620. http://dx.doi.org/10.1136/gut.2006.107714

[21] Veerappan, G.R., Perry, J.L., Duncan, T.J., Baker, T.P., Maydonovitch, C., Lake, J.M., Wong, R.K. and Osgard, E.M. (2009) Prevalence of eosinophilic esophagitis in an adult population undergoing upper endoscopy: A prospective study. Clinical Gastroenterology and Hepatology, 7, 420-426. http://dx.doi.org/10.1016/j.cgh.2008.10.009

[22] Gupta, S.K., Fitzgerald, J.F., Chong, S.K., Croffie, J.M. and Collins, M.H. (1997) Vertical lines in distal esophageal mucosa (VLEM): A true endoscopic manifestation of esophagitis in children? Gastrointest Endosc, 45, 485489. http://dx.doi.org/10.1016/S0016-5107(97)70178-0

[23] Moy, N., Heckman, M.G., Gonsalves, N., Achem, S.R. and Hirano, I. (2011) Inter-observer agreement on endoscopic esophageal findings in eosinophilic esophagitis (EoE). Gastroenterology, 140, S236.

[24] Peery, A.F., Cao, H., Dominik, R., Shaheen, N.J. and Dellon, E.S. (2011) Variable reliability of endoscopic findings with white-light and narrow-band imaging for patients with suspected eosinophilic esophagitis. Clinical Gastroenterology and Hepatology, 9, 475-480. http://dx.doi.org/10.1016/j.cgh.2011.02.026

[25] Parfitt, J.R., Gregor, J.C., Suskin, N.G., Jawa, H.A. and Driman, D.K. (2006) Eosinophilic esophagitis in adults: Distinguishing features from gastroesophageal reflux disease: A study of 41 patients. Modern Pathology, 19, 9096. http://dx.doi.org/10.1038/modpathol.3800498

[26] Mikhak, Z. and Luster, D. (2009) Chemokines in cell movement and allergic inflammation. In: Adkinson Jr., N.F., Busse, W.W., Bochner, B.S., Holgate, S.T., Simons, E.R. and Lemanske Jr., R.F., Eds., Middleton's Allergy 
Principles \& Practice, 7th Edition, Mosby Elsevier, New York, 181-201.

http://dx.doi.org/10.1016/B978-0-323-05659-5.00011-5

[27] Potter, J.W., Saeian, K., Staff, D., Massey, B.T., Komorowski, R.A., Shaker, R. and Hogan, W.J. (2004) Eosinophilic esophagitis in adults: An emerging problem with unique esophageal features. Gastrointest Endosc, 59, 355-361.

http://dx.doi.org/10.1016/S0016-5107(03)02713-5

[28] Carr, S. and Watson, W. (2011) Eosinophilic esophagitis. Allergy Asthma Clinical Immunology, 7, S8. http://dx.doi.org/10.1186/1710-1492-7-S1-S8

[29] Noel, R.J., Putnam, P.E. and Rothenberg, M.E. (2004) Eosinophilic esophagitis. The New England Journal of Medicine, 351, 940-941. http://dx.doi.org/10.1056/NEJM200408263510924

[30] Brown-Whitehorn, T.F. and Spergel, J.M. (2010) The link between allergies and eosinophilic esophagitis: Implications for management strategies. Expert Review of Clinical Immunology, 6, 101-109. http://dx.doi.org/10.1586/eci.09.74

[31] Klauser, A.G., Schindlbeck, N.E. and Muller-Lissner, S.A. (1990) Symptoms in gastro-oesophageal reflux disease. Lancet, 335, 205-208. http://dx.doi.org/10.1016/0140-6736(90)90287-F

[32] Kapel, R.C., Miller, J.K., Torres, C., Aksoy, S., Lash, R. and Katzka, D.A. (2008) Eosinophilic esophagitis: A prevalent disease in the United States that affects all age groups. Gastroenterology, 134, 1316-1321. http://dx.doi.org/10.1053/j.gastro.2008.02.016

[33] Attwood, S.E., Smyrk, T.C., Demeester, T.R. and Jones, J.B. (1993) Esophageal eosinophilia with dysphagia. A distinct clinicopathologic syndrome. Digestive Diseases and Sciences, 38, 109-116.

http://dx.doi.org/10.1007/BF01296781

[34] Kim, H.P., Vance, R.B., Shaheen, N.J. and Dellon, E.S. (2012) The prevalence and diagnostic utility of endoscopic features of eosinophilic esophagitis: A meta-analysis. Clinical Gastroenterology and Hepatology, 10, 988-996. http://dx.doi.org/10.1016/j.cgh.2012.04.019

[35] Mackenzie, S.H., Go, M., Chadwick, B., Thomas, K., Fang, J., Kuwada, S., Lamphier, S., Hilden, K. and Peterson, K. (2008) Eosinophilic oesophagitis in patients presenting with dysphagia-A prospective analysis. Alimentary Pharmacology \& Therapeutics, 28, 1140-1146. http://dx.doi.org/10.1111/j.1365-2036.2008.03795.x

[36] Orenstein, S.R., Shalaby, T.M., Di Lorenzo, C., Putnam, P.E., Sigurdsson, L., Mousa, H. and Kocoshis, S.A. (2000) The spectrum of pediatric eosinophilic esophagitis beyond infancy: A clinical series of 30 children. American Journal of Gastroenterology, 95, 1422-1430. http://dx.doi.org/10.1111/j.1572-0241.2000.02073.x

[37] Rothenberg, M.E., Mishra, A., Collins, M.H. and Putnam, P.E. (2001) Pathogenesis and clinical features of eosinophilic esophagitis. Journal of Allergy and Clinical Immunology, 108, 891-894.

http://dx.doi.org/10.1067/mai.2001.120095

[38] Lee, R.G. (1985) Marked eosinophilia in esophageal mucosal biopsies. American Journal of Surgical Pathology,
9, 475-479.

http://dx.doi.org/10.1097/00000478-198507000-00002

[39] Steiner, S.J., Gupta, S.K., Croffie, J.M. and Fitzgerald, J.F. (2004) Correlation between number of eosinophils and reflux index on same day esophageal biopsy and 24 hour esophageal pH monitoring. American Journal of Gastroenterology, 99, 801-805. http://dx.doi.org/10.1111/j.1572-0241.2004.04170.x

[40] Desai, T.K., Stecevic, V., Chang, C.H., Goldstein, N.S., Badizadegan, K. and Furuta, G.T. (2005) Association of eosinophilic inflammation with esophageal food impaction in adults. Gastrointestinal Endoscopy, 61, 795-801. http://dx.doi.org/10.1016/S0016-5107(05)00313-5

[41] Remedios, M., Campbell, C., Jones, D.M. and Kerlin, P. (2006) Eosinophilic esophagitis in adults: Clinical, endoscopic, histologic findings, and response to treatment with fluticasone propionate. Gastrointestinal Endoscopy, 63, 3-12. http://dx.doi.org/10.1016/j.gie.2005.07.049

[42] Morrow, J.B., Vargo, J.J., Goldblum, J.R. and Richter, J.E. (2001) The ringed esophagus: Histological features of GERD. American Journal of Gastroenterology, 96, 984989. http://dx.doi.org/10.1111/j.1572-0241.2001.03682.x

[43] Dent, J., El-Serag, H.B., Wallander, M.A. and Johansson, S. (2005) Epidemiology of gastrooesophageal reflux disease: A systematic review. Gut, 54, 710-717. http://dx.doi.org/10.1136/gut.2004.051821

[44] Voutilainen, M., Sipponen, P., Mecklin, J.P., Juhola, M. and Färkkilä, M. (2000) Gastroesophageal reflux disease: Prevalence, clinical, endoscopic and histopathologic findings in 1,128 consecutive patients referred for endoscopy due to dyspeptic and reflux symptoms. Digestion, 61, 6-13. http://dx.doi.org/10.1159/000007730

[45] Foroutan, M., Norouzi, A., Molaei, M., Mirbagheri, S.A., Irvani, S., Sadeghi, A., Derakhshan, F., Tavassoli, S., Besharat, S. and Zali, M. (2010) Eosinophilic esophagitis in patients with refractory gastroesophageal reflux disease. Digestive Diseases and Sciences, 55, 28-31. http://dx.doi.org/10.1007/s10620-008-0706-z

[46] Molina-Infante, J., Ferrando-Lamana, L., Mateos-Rodriguez, J.M., Pérez-Gallardo, B. and Prieto-Bermejo, A.B. (2008) Overlap of reflux and eosinophilic esophagitis in two patients requiring different therapies: A review of the literature. World Journal of Gastroenterology, 14, 1463-1466. http://dx.doi.org/10.3748/wjg.14.1463

[47] Lind, T., Havelund, T., Carlsson, R., Anker-Hansen, O., Glise, H., Hernqvist, H., Junghard, O., Lauritsen, K., Lundell, L., Pedersen, S.A. and Stubberöd, A. (1997) Heartburn without oesophagitis: Efficacy of omeprazole therapy and features determining therapeutic response. Scandinavian Journal of Gastroenterology, 32, 974-979. http://dx.doi.org/10.3109/00365529709011212

[48] Smout, A.J.P.M. (1997) Endoscopy-negative acid reflux disease. Alimentary Pharmacology \& Therapeutics, 11, 8185. http://dx.doi.org/10.1111/j.1365-2036.1997.tb00798.x

[49] Modlin, I.M., Hunt, R.H., Malfertheiner, P., Moayyedi, P., Quigley, E.M., Tytgat, G.N., Tack, J., Heading, R.C., Holtman, G., Moss, S.F. and Vevey NERD Consensus Group (2009) Diagnosis and management of non-erosive reflux disease-The Vevey NERD Consensus Group. 
Digestion, 80, 74-88.

[50] Weusten, B.L., Akkermans, L.M., vanBerge-Henegouwen, G.P. and Smout, A.J. (1995) Symptom perception in gastroesophageal reflux disease is dependent on spatiotemporal reflux characteristics. Gastroenterology, 108, 17391744. http://dx.doi.org/10.1016/0016-5085(95)90135-3

[51] Cicala, M., Emerenziani, S., Caviglia, R., Guarino, M.P., Vavassori, P., Ribolsi, M., Carotti, S., Petitti, T. and Pallone, F. (2003) Intra-oesophageal distribution and perception of acid reflux in patients with non-erosive gastro-oesophageal reflux disease. Alimentary Pharmacology \& Therapeutics, 18, 605-613.

http://dx.doi.org/10.1046/j.1365-2036.2003.01702.x

[52] Cicala, M., Gabbrielli, A., Emerenziani, S., Guarino, M.P., Ribolsi, M., Caviglia, R. and Costamagna, G. (2005) Effect of endoscopic augmentation of the lower oesophageal sphincter (Gatekeeper reflux repair system) on intraoesophageal dynamic characteristics of acid reflux. Gut, 54, 183-186.

http://dx.doi.org/10.1136/gut.2004.040501
[53] Emerenziani, S., Zhang, X., Blondeau, K., Silny, J., Tack, J., Janssens, J. and Sifrim, D. (2005) Gastric fullness, physical activity, and proximal extent of gastroesophageal reflux. American Journal of Gastroenterology, 100, 12511256. http://dx.doi.org/10.1111/j.1572-0241.2005.41695.x

[54] Bredenoord, A.J., Weusten, B.L., Curvers, W.L., Timmer, R. and Smout, A.J. (2006) Determinants of perception of heartburn and regurgitation. Gut, 55, 313-318. http://dx.doi.org/10.1136/gut.2005.074690

[55] Bredenoord, A.J., Weusten, B.L., Timmer, R. and Smout, A.J. (2006) Characteristics of gastroesophageal reflux in symptomatic patients with and without excessive esophageal acid exposure. American Journal of Gastroenterology, 101, 2470-2475.

http://dx.doi.org/10.1111/j.1572-0241.2006.00945.x 